\title{
The Relationship between FDI, Economic Growth and Financial Development in Cabo Verde
}

\author{
Leandro do Rosário Viana Duarte ${ }^{1}$,Yin Kedong ${ }^{1} \&$ Li Xuemei $^{1}$ \\ ${ }^{1}$ School of Economics, Ocean University of China, Qingdao, China \\ Correspondence: Li Xuemei, Department of Finance, School of Economics, Ocean University of China, 238 \\ Songling Road, Qingdao, Shandong, 266100, China. Tel: 86-185-6135-4087. E-mail: lixuemei@ ouc.edu.cn
}

Received: March 21, 2017

Accepted: April 20, 2017

Online Published: April 25, 2017

doi:10.5539/ijef.v9n5p132

URL: https://doi.org/10.5539/ijef.v9n5p132

\begin{abstract}
This paper examines the relationship between foreign direct investment (FDI), economic growth and financial development in Cabo Verde for the period 1987-2014.The methodology involves the use of bound test approach to cointegration (ARDL) as well as the ECM-Granger causality analysis. The bound test indicated that there is a long-run relationship when the variable GDP and FDI are the dependent variable. Moreover, the results indicated that FDI has a positive effect on the economic growth in Cabo Verde. It also found a bidirectional causality between FDI and economic growth, i.e. FDI granger causes GDP and GDP granger cause FDI. Thus, we concluded that higher levels of FDI inflow mean higher levels of economic growth and vice versa for the economy of Cabo Verde. Furthermore, we found that both economic growth and domestic credit to private sector are important factors in stimulating the FDI into the country. These results found are important for the country policymakers to take appropriate measures to enhance and improve the condition for FDI inflow in Cabo Verde.
\end{abstract}

Keywords: FDI, economic growth, financial development, ARDL Cointegration, Cabo Verde

\section{Introduction}

Foreign capital, particularly FDI, has been increasing all over the world and it has an important role in promoting the economy of many countries. Consequently, many countries have adjusted their FDI policy framework offering certain conditions to attract FDI, such as taxes deductions and other incentives.

Over these past decades' various studies have investigated the relationship between financial development, FDI, and economic growth. FDI enhances economic growth through technological spillovers. According to Barro and Sala-i-Martin (1995), De Jager (2004), and Romer (1990) these technological spillovers can boost the present stock of knowledge through labor mobility, training and through managerial skills and organizational arrangements. The FDI inflows can play a significant role in increasing and enhancing the supply of funds for domestic investment in the host country (Belloumi, 2014).

In particular, the role that FDI plays in the host country economy depends on the country-specific factors as pointed it out by many authors. For example, researchers argue that financial markets can play an important role in determining the FDI inflow in the host country. For the country to take advantage of the amount of FDI inflow into the country, a certain level of financial development is required. The development of domestic financial systems contribute to mobilizing saving, screen and monitor investment projects, which lead to higher economic growth, thus FDI and domestic financial market are complementary in the role of increasing the rate of economic growth (Hermes \& Lensink, 2003).

According to Bertocco (2008), financial market development involves improvements in the production of ex-ante information about possible investments, monitoring of investments, employment of corporate governance, trading, diversification, management of risk, mobilization, pooling of savings, and exchange of goods and services. The financial sector is important due to its determinant role in the resource allocation.

Cabo Verde is a country with weak financial intermediation and scarce natural resources. Its economy depends strongly on the others countries. Therefore, the government offers many incentives, such as taxes deduction, to attract foreign capital to boost the economy of the country. The increase in the foreign investment in the country is expected to trigger spillovers effects, such as reduction of the unemployment rate, promotion of exports, acquirement of advanced technology from the foreign investment and improvement of domestic market with the 
knowledge brought by foreign firms. The emphasis of FDI as a main factor of economic growth of the country pointed it out by several economics reports, such as BCV (2015) economic report and Nshimyumuremyi and Simpasa (2016) economic report; indicating that the economic growth is correlated with the amount of FDI inflow into the country. Even though FDI seems to have an important role in the economy of Cabo Verde, few researches using econometrics analysis were made to examine the relevant importance of FDI on the economy of the Country. In this study, we used the autoregressive distributed lag to determine the long-run and short-run relationship as well as the directional of causality between the variables economic growth per capita (GDP), inflation, FDI inflow, domestic credit to private sector (DCPS) and money supply $\left(\mathrm{M}_{2}\right)$. With the analysis employed, the results can be relevant to improve the economic situation in Cabo Verde. The paper is divided into various section; section 2 provide the overview of the economy of Cabo Verde; section 3 the literature review; section 4 the model specification, section 5 provides the empirical results and section 6 provides the conclusion.

\section{Overview of the Economy of Cabo Verde}

The economy of Cabo Verde in these past several years is accompanied by a remarkable economic growth and several achievements. The economy of Cabo Verde is concentrated in services, which represent a significant proportion of the country Gross Domestic Product.

From 1975 to around 1993, GDP per capita grew annually at a rate of between 3\% and 4\%, achieved primarily by allocating scarce capital to the most productive investments, along with cheap labor which productivity gradually rose due to the policy of universal access to education from independence onwards (AfDB, 2012). From 2000 to 2008, the average annual GDP growth rate was around $6.62 \%$. From 1994 to 2014, Cabo Verde had an average annual GDP growth rate of some $5.56 \%$.

The main reason for this economic growth was caused by a series of changes in National economic policy in the early part of 1991; by assuming the policy of the economy liberalization. Thus, these reforms include privatization in some business sector of government, greater supervision on the expenditures and more rigorous collection of revenues. Furthermore, reforms in the financial sector such as limitation of credit to the public sector, modifying the interest rate policy and moving from direct monetary control to indirect control, structural reforms in external trade with the liberalization of trade, and removal of the state monopoly in relation to imports. Another important reason was the level of exchange rate policy with Cabo Verdean escudo being pegged to the euro, which preserves the value of the local currency and the country's external competitiveness (Semedo, 2007).

Despite this remarkable achievements, Cabo Verde's economy still facing several issues such as huge government debt, high unemployment rate (WorldBank, 2016). Nonetheless, the economy of Cabo Verde depends strongly on other countries, due to the lack of natural resources, small market size and unfavorable condition for the practicing of agriculture. Therefore, as an alternative, the government of Cabo Verde, seeks for foreign investment as the motor to boost the country's economic growth. It vigorously seeks to attract investment to the country that stimulates business activities and renovates the country's economic structure. Most emphasis is placed on the export-oriented industries and tourism. In 2012, tourism a dominant part of the tertiary sector represented about 70\% of GDP. The agriculture accounted for less than 10\% of GDP (Note 1), which illustrated the poor participation of agriculture in the development of the country (AfDB, 2014).

According to BCV (2015) report, the financial account recorded a net inflow of funds of $3.6 \%$ of GDP in 2015 compared to $6.9 \%$ in 2014. The poor performance of the financial sector was due to the contraction of FDI and external loans.

FDI is considered to be one of the main factors responsible for the development of the Cabo Verdean economy and for many people, it's the way forward for the country to achieve its future economic prospects. In this perspective, the Government recognizes the need to remove barriers from FDI to improve the rate of implementation of projects.

In the recent times, the low level of corruption and the social and political stability have been an important factor in attracting foreign direct investment. For the period from 1986 to 2010, the annual average of FDI was $4.5 \%$ of GDP. The FDI started to have an impact on the Cabo Verdean production with the privatization of some public enterprises. The tourism sector was dominant, with $76 \%$ of total FDI, followed by financial services (Note 2) with 10\% (Brito, 2014). However, according to UNCTAC from 2008 to 2013, there was a significant decline, ranging from US \$ 200 million in 2008 to around US \$ 71 million in 2013 (Note 3).

The international economic and financial crisis has conditioned the recent evolution of foreign direct investment in Cabo Verde. Alongside the decline in FDI inflow, the economic growth suffered a contraction. The contraction started in 2007, with GDP growth dropping from $8.6 \%$ to $6.6 \%$ in 2008, and further declining to $-1.27 \%$ in 2009 
as illustrated in figure 1. After 2009, the economy started to recover; increasing from $-1.27 \%$ to $1.47 \%$ in 2010 and $4 \%$ in 2011. For the subsequent years, GDP growth dropped from $4 \%$ in 2011 to $1.1 \%$ in 2012 and $1 \%$ in 2013 (Note 4).

The economy of Cabo Verde in 2014 grew by $1.8 \%$, driven by the recovery of FDI and the increase in remittances from emigrants that have boosted household consumption and provided support for many Cabo Verdeans (Nshimyumuremyi \& Simpasa, 2016).

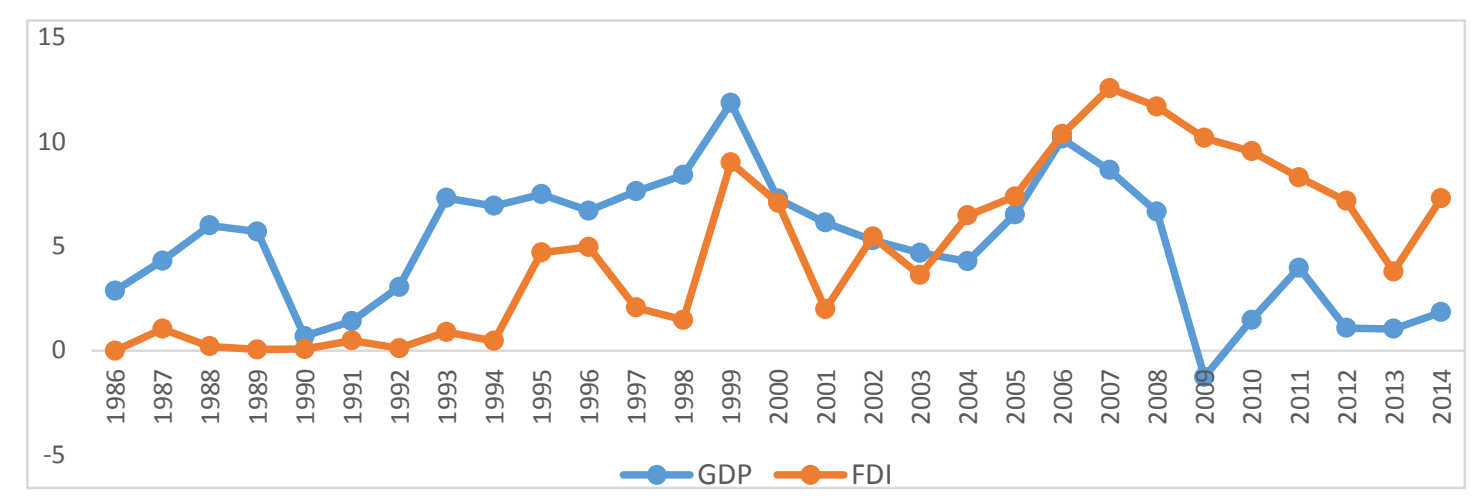

Figure 1. The relationship between FDI and economic growth

\section{Brief Literature Review}

The analysis of foreign direct investment (FDI) on the economic growth has been given much attention in these past decades due to its capability to help in the development process of the economy. FDI is often referred to as a vehicle of technical progress by introducing management practices, advanced technology, and improved production techniques; it recognized that FDI could improve productivity (Borensztein, De Gregorio, \& Lee, 1998). The modern idea about the effects of FDI on economic growth differs from conventional models. According to the neoclassical point of view, FDI does not influence the long-run growth rate, but only the level of output. An exogenous increase in FDI would increase the amount of capital and income per capita temporarily as diminishing returns would impose a limit to this growth in the long-run (Belloumi, 2014).

FDI inflows given an appropriate host country condition and a basic level of development are expected to contribute to the economic growth by triggers technology spillovers, human capital formation, contributing to international trade integration, creating a more competitive business environment and enhances firms development (OECD, 2002).

The analyze of the impact of FDI on the economic growth do not only extend to FDI but also to others factors such as the country economic development situation, the magnitude of the country to absorb the positive effects of FDI and others internal and external factors. Studies by Blomstrom, Lipsey, and Zejan (1992) found that inward FDI is a source of economic growth only for a country already at the certain level of development. They suggested that a certain threshold level of development was necessary if the host country wants to absorb new technology from a foreign country.

Many authors such as Hermes and Lensink (2003), Alfaro, Chanda, Kalemli-Ozcan, and Sayek (2004), Azman-Saini, Law, and Ahmad (2010), in their analysis found that financial development plays an important role in the economic growth and FDI has a positive effect on the economic growth in countries that have a developed financial market. These studies emphasize that countries need not only a sound banking system but also an effective financial market to permit entrepreneurs to acquire credit to start a new business or expand an existing one.

Borensztein et al. (1998), and Romer (1990) stated that stock of human capital is determinant for growth, that too little human capital is devoted to research in equilibrium, that integration into world markets will increase growth rates. According (Razmi \& Refaei, 2013) open economies achieve high economic growth rates than closed economies.

Several econometrics models were applied to determine the effects of FDI on the economic growth. For example, Balasubramanyam, Salisu, and Sapsford (1996) used cross-section data and OLS regressions for 46 developing countries to evaluate the effects of FDI on the economic growth. According to them, the growth effects of FDI on the economic growth is positive. However, these positive effects are restricted to host countries that have 
adopted export-promoting policies. Borensztein et al. (1998) used cross-section data for 69 developing countries during the period 1970 to 1989 . They found out that FDI has a positive effect on economic growth, but this positive effect was depending on the level of human capital in the host country. Alfaro et al. (2004) using panel data analysis during the period of 1975 to 1995 found that FDI contribute significantly to increase the economic growth but the level of development of local financial markets was crucial for these positive effects. Bengoa and Sanchez-Robles (2003) using panel data framework for 18 Latin American countries over the period 1970-99, concluded that for a positive effect from FDI to be achieved, the host country must have an adequate level of economic stability, human capital and liberalized capital markets. Furthermore, Azman-Saini et al. (2010) examined the data from 91 countries over the period 1975-2005. The results illustrated a positive effect of FDI on economic growth, only when the financial markets development exceeds a threshold level.

Research examined the impact of FDI on economic growth in Cabo Verde using VAR models and Granger Causality (GC) test over the period of 1987 to 2008 indicated a unidirectional relationship between GDP and FDI, i.e. GDP Granger causes FDI, but not the reverse. Moreover, the results indicated that the impact of an exogenous shock in error terms of GDP had a long persistence in the behavior of the FDI (Alves, 2011). Almfraji, Almsafir, and Yao (2014) using VAR model analyzed the relationship between FDI and economic growth in Qatar from the period of 1990 until 2010. They found that FDI inflows and economic growth interact with each other in relative long term.

On the other hand, many studies have analyzed the relationship between FDI and economic growth using bound test for cointegration approach alongside with error correction model (ECM) Granger causality analysis. A study conducted by Blin and Ouattara (2009) using auto-regressive distributed lag (ARDL) over the period of 1975-2001, demonstrated that FDI has a significant impact on economic growth in Mauritius.

Recently, Dritsaki and Stiakakis (2014) applied the bound test (ARDL) and the ECM-ARDL to determine the relationship between FDI, exports and economic growth in Croatia over the period of 1994-2012. They found a bidirectional long-run and short-run causal relationship between exports and growth, while FDI did not have a positive impact on the economic growth. Belloumi (2014) has investigated the relationship between trade, FDI and economic growth in Tunisia by applying bound testing (ARDL) approach to cointegration. The results indicated that there was no significant Granger causality from FDI to economic growth or from economic growth to FDI in the short run for the period of 1970 to 2008.

Following the same approach, Bekhet and Al-Smadi (2015) used bound test for cointegration and granger causality to analyze the long-run and short-run relationship among FDI, GDP, SMI, $\mathrm{M}_{2}$ and Economic openness (EO). They found a long-run and short-run relationship between FDI and its determinant, and the granger causality suggests a different causal relationship among the variables in the study.

Faisal, Muhamad, and Tursoy (2016) used ARDL model, for investigating the relationship between economic growth, stock price, FDI and domestic credit to private sector in China. The results indicated a unidirectional short-run Granger causality from stock prices to economic growth and from economic growth to FDI.

The above literature review, clearly demonstrated the importance of investigating the impacts of FDI on the economic growth as well as the role of financial development on the economic growth of Cabo Verde. This study will contribute to the literature given that few researches have been made in this area. Moreover, provide a solid background of the economic situation of the country enabling the seeking of appropriate measures to improve the economic growth.

\section{Data Source and Methodology}

\subsection{Model Construction and Data Source}

The general model used in this paper based on the new endogenous growth theory (Note 5) is built upon the following augment production function.

$$
Y=f\left(F D I, D C P S, M_{2}, I N F\right)
$$

Where y is the economic growth per capita (GDP), FDI is the amount of FDI inflow into the country, DCPS is domestic credit to private sector, $\mathrm{M}_{2}$ is the money supplied and INF is the inflation rate. The annual times series cover a period of 27 years from the year 1987 until 2014. The data have been obtained from World development indicators (WDI) and United Nations Conference on Trade and Development (UNCTAD). The data corresponding to GDP and FDI are sourced from UNCTAD and the rest of the variables are sourced from WDI. Economic growth is measured as an averaged GDP growth per capita, FDI, $\mathrm{M}_{2}$, and DCPS are measured as a percentage of GDP; inflation rate is given in annual percentage. This Study uses EVIEWS 9 for the analysis.

Many of the above mention variables were widely used in literature studies such as made by Borensztein et al. 
(1998), Bengoa and Sanchez-Robles (2003), Alfaro et al. (2004), Azman-Saini et al. (2010), Belloumi (2014), and Bekhet and Al-Smadi (2015).

\subsection{Unit Root Test}

To employ autoregressive distributed lag (ARDL) bound test in this study several steps were performed. First, we examined the stationarity of the variables to see the order of integration. To do the analysis of stationarity, we used the conventional Augment Dicked Fuller test (ADF) by Dickey and Fuller (1979) and the Phillips- Perron test (PP) by Phillips and Perron (1988). The ADRL bound test is based on the assumption that the order of integration is either $\mathrm{I}(0)$ or $\mathrm{I}(1)$. In the case of $\mathrm{I}(2)$, the results can be spurious which makes the ADRL bound test not suitable (Pesaran \& Shin, 1998).

Table 2 provides the unit root for the variables in the analysis. The results are estimated using ADF test and Philip's Peron (PP) test. We test the presence of unit root using intercept and trend. Inflation rate was the only variable stationary at level using just intercept. However, when the trend was included the variables, $\mathrm{M}_{2}$ and DCPS were stationary at level. In general, all variables were stationary at I (0) and I (1) which indicated that the bound test approach would be suitable.

\subsection{ARDL Bound Test for Cointegration}

The ARDL cointegration technique was developed by Pesaran and Shin (1999) and extended by Pesaran, Shin, and Smith (2001). According to Pesaran and Shin (1998), the ARDL technique has the advantage of providing consistent estimates of the long-run coefficients that are asymptotically normal irrespective of whether the underlying regressors are (1) or I(0). Besides that, the ARDL approach is more efficient for small sample data. Pesaran and Shin (1998) show that the OLS estimators of the short-run parameters are consistent and the ARDL based estimators of the long-run coefficients are super-consistent in small sample sizes.

The estimation model for the variables can use the following ADRL model:

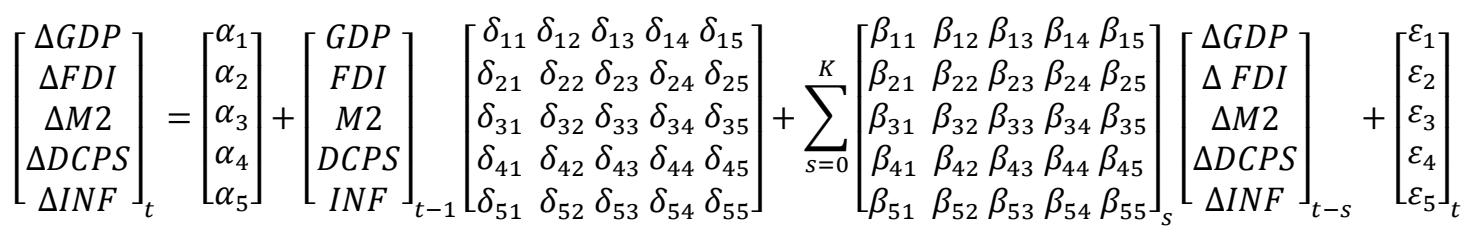

Where $\Delta$ denotes the first difference operator, $\alpha(\mathrm{i}=1, \ldots .5)$, indicates the constant, $\delta_{\mathrm{ij}} \mathrm{s}(\mathrm{i}, \mathrm{j}=1, \ldots .5)$ and $\varepsilon_{i t} s$ are the error term for $(\mathrm{i}=1,2 \ldots 5)$. The others variables are defined previously.

Pesaran et al. (2001) developed two type of F-statistic, the OLS bound F-statistics values and bound F test for critical values. The bound test is based on the assumption of joint significance of the F-statistic test where the null hypothesis of no cointegration is tested against the alternative hypothesis of cointegration. The $\mathrm{F}$ statistic developed by Pesaran et al. (2001) is non-standard. Therefore, the null hypothesis of no cointegration for our analysis can be written as $\mathrm{H}_{0}$ : $\delta_{\mathrm{ij}} \mathrm{s}=0$ against the alternative hypothesis of cointegration $\mathrm{H}_{1}: \delta_{\mathrm{ij}} \mathrm{s} \neq 0$. The null hypothesis of no cointegration is not rejected when the F- statistics is less than the lower critical bound value (LCB) and there is cointegration if F-statistics is greater than the upper critical bound value. Otherwise, the cointegration test is inconclusive. Moreover, the dynamic error model was employed from the bounds ARDL test, which reintroduce the long-run information lost through differencing using the estimating lagged error correction model $\left(E C M_{t-1}\right)$.

After examining the long-run relationship between variables, we employed Granger causality test. The granger causality test used in the current study following the model of Odhiambo (2009), Narayan and Smyth (2008) and Belloumi (2014). According to Odhiambo (2009), the existence of a long-run relationship between the variables suggests that there must be Granger-causality in at least one direction. However, the direction of this causality can only be determined by F- statistic and error correction term. The dynamic error correction model includes the short-run alongside with the long-run equilibrium. The error correction method based on our analysis can be expressed as follow:

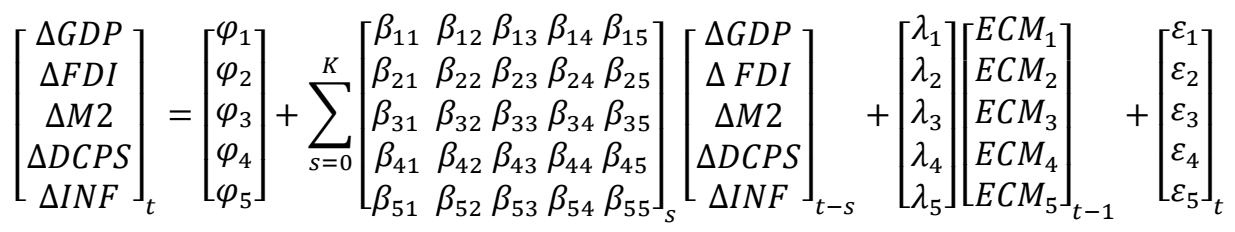

Where $\varphi_{i}(\mathrm{i}=1 \ldots 5)$ represents the constants of the models; $\beta_{i j} s i, j=1 \ldots 5$ denotes the short-run coefficients; 
$\lambda \mathrm{i}(\mathrm{i}=1 \ldots 6)$ represents the coefficients of $E C M_{i, t-1}$ which illustrated the adjustments from the short-run to the long-run of the variables among the variables. $\mathrm{k}$ represents the lag length; $\mathrm{s}$ is the lag order and $\varepsilon_{i}(i=1 \ldots 5)$ is the disturbance terms assumed to be uncorrelated with zero means, $\mathrm{N}\left(0, \sigma^{2}\right)$.

\section{Empirical Results}

Table 1, provides the descriptive statistics and the correlation matrix. The table indicates that economic growth has a positive correlation with FDI, $\mathrm{M}_{2}$ and inflation rate. On the other hand, economic growth has a negative correlation with domestic credit to private sector. FDI has a strong positive correlation between the variables domestic credit private sector and $\mathrm{M}_{2}$, while it has a negative correlation with inflation. The highest correlation occurs between the variables $\mathrm{M}_{2}$ and DCPS. It is also noteworthy that the variable DCPS and $\mathrm{M}_{2}$ are both negative correlated with the inflation rate.

Table 1. Descriptive statistics and correlation matrix

\begin{tabular}{lccccc}
\hline & GDP & FDI & DCPS & M $_{2}$ & INF \\
\hline Mean & 3.408247 & 4.942293 & 65.11022 & 37.79672 & 3.822947 \\
Median & 3.931942 & 4.830436 & 67.67084 & 34.79628 & 3.960114 \\
Maximum & 9.336403 & 12.57594 & 94.46069 & 65.74181 & 10.65351 \\
Minimum & -1.848392 & 0.057019 & 31.44315 & 14.55164 & -2.477457 \\
Std.Dev & 2.956350 & 3.994215 & 18.86488 & 16.14297 & 3.185985 \\
Jarque Bera & 0.274363 & 2.058294 & 2.324622 & 2.176610 & 0.173961 \\
Probably & 0.871812 & 0.357312 & 0.312763 & 0.336787 & 0.916695 \\
GDP & 1.000000 & & & & \\
FDI & 0.297374 & 1.000000 & & & \\
DCPS & -0.159017 & 0.755441 & 1.000000 & & \\
M & 0.111819 & 0.73083 & 0.820280 & 1.000000 & \\
INF & 0.063446 & -0.306 & -0.410389 & -0.456517 & 1.000000 \\
\hline
\end{tabular}

Table 2. Unit root

\begin{tabular}{|c|c|c|c|c|c|c|c|c|}
\hline \multirow[t]{3}{*}{ Variables } & \multicolumn{4}{|c|}{$\mathrm{ADF}$} & \multicolumn{4}{|c|}{ PP } \\
\hline & \multicolumn{2}{|c|}{ Level } & \multicolumn{2}{|c|}{ First difference } & \multicolumn{2}{|c|}{ Level } & \multicolumn{2}{|c|}{ First difference } \\
\hline & Constant & Trend & Constant & Trend & Constant & Trend & Constant & Trend \\
\hline GDP & -2.47 & -2.43 & $-5.02 * * *$ & $-4.91 * * *$ & -2.60 & -2.57 & $-5.26 * * *$ & $-5.15 * * *$ \\
\hline FDI & -1.83 & -2.84 & $-5.78 * * *$ & $-5.08 * * *$ & -1.71 & -2.85 & $-7.29 * * *$ & $-7.58 * * *$ \\
\hline DCPS & -0.13 & $-2.78 * *$ & $-5.65^{* * *}$ & $-5.44 * * *$ & -0.94 & -2.84 & $-5.64 * * *$ & $-5.44 * * *$ \\
\hline $\mathrm{M}_{2}$ & -0.88 & $-3.77 * *$ & $-3.71 * * *$ & $-3.66^{* *}$ & -0.95 & -2.01 & $-3.72 * * *$ & $-3.67 * *$ \\
\hline INF & $-3.13 * *$ & $-3.95 * *$ & & & $-3.18 * *$ & $-2.95^{* *}$ & & \\
\hline
\end{tabular}

\subsection{ARDL Test for Cointegration}

Table 3 shows the bound test for co-integration and the result for the series model. When GDP is the dependent variable the results indicated that $\mathrm{F}_{\mathrm{GDP}}\left(\mathrm{FDI}, \mathrm{INF}, \mathrm{M}_{2}, \mathrm{DCPS}\right)=3.7514$; for FDI model, $\mathrm{F}_{\mathrm{FDI}}$ (GDP, INF, $\mathrm{M}_{2}$, DCPS $)=3.99$, for DCPS model, $\mathrm{F}_{\mathrm{DCPS}}\left(\mathrm{FDI}, \mathrm{M}_{2}\right.$, INF, GDP)=0.94; for $\mathrm{M}_{2}$ model, $\mathrm{F}_{\mathrm{M} 2}$ (GDP, FDI, DCPS, INF)= 2.02 and for inflation model $\mathrm{F}_{\mathrm{INF}}\left(\mathrm{FDI}, \mathrm{GDP}, \mathrm{M}_{2}, \mathrm{DCPS}\right)=2.22$. The results indicated that there is a long-run relationship among the variables when GDP and FDI are dependent variables while for the others variables we did not reject the null hypothesis of no cointegration. For GDP and FDI as a dependent variable, the F-statistics of 3.75 and 3.99 are higher than the upper bound critical value at 10 percent significance level. These results indicated that the variables share a long-run relationship; therefore, we can proceed with the estimation of a long-run and short-run for the variables GDP and FDI as dependent variables.

Table 3. Cointegration test results

\begin{tabular}{lccccc}
\hline Equation model & F-statistics & AIC lag length criteria & \multicolumn{2}{c}{ Bound critical values } & Decision \\
\cline { 3 - 5 } & & & $\mathrm{I}(0)$ & $\mathrm{I}(1)$ & \\
\hline $\mathrm{F}_{\mathrm{GDP}}$ (FDI, INF, M2, DCPS) & $3.75^{*}$ & $(1,2,2,0,2)(1,0,0,2,2)$ & 3.74 & 5.74 & Cointegrated \\
$\mathrm{F}_{\mathrm{FDI}}$ (GDP, INF, M2, CPS) & $3.99^{*}$ & $(2,2,0,0,0)$ & 2.86 & 4.01 & Cointegrated \\
$\mathrm{F}_{\mathrm{DCPS}}$ (FDI, M2, INF, GDP) & 0.94 & $(1,0,0,0,0)$ & 2.45 & 3.52 & No cointegration \\
$\mathrm{F}_{\mathrm{M} 2}$ (GDP, FDI, DCPS, INF) & 2.02 & $(1,2,0,1,0)$ & & No cointegration \\
$\mathrm{F}_{\mathrm{INF}}$ (FDI, GDP, M2, DCPS) & 2.22 & & & No cointegration \\
\hline
\end{tabular}

***Denotes statistical significance at $1 \%$ level. ** Denotes statistical significance at 5\% level. * Denotes statistical significance at $10 \%$ level. 


\subsection{Long-Run and Short-Run Analysis}

Table 4, presents the long-run coefficients for the models estimated. With GDP as the dependent variable, the results illustrated that FDI and $\mathrm{M}_{2}$ have a positive significant relationship with economic growth at 5\% and 10\% level respectively. On the other hand, inflation rate was not statistically significant. The empirical results obtained for the long-run indicated that increasing FDI and $\mathrm{M}_{2}$ increase economic growth in the country. These results consist with the findings by Alkhuzaim (2014) for Qatar, Bekhet and Al-Smadi (2015) for Jordan. Besides, the results indicated that DCPS has a negative relationship with economic growth. Similar results were found by and Ariç (2014) for European Union, and Cetin (2016) for Turkey.

Regarding FDI model, both economic growth and domestic credit to private sector were positive and statistically significant at 5\% and 10\% significance level. This indicated that economic growth, as well as domestic credit to private sector, are an important determinant for the quantity of FDI that the country received. The result goes in line with the results found by Alves (2011) which indicate that economic growth stimulates FDI in Cabo Verde.

Table 4. Long-run coefficients

\begin{tabular}{lcccccccc}
\hline Equation model & Constant & $\mathrm{GDP}_{\mathrm{t}-1}$ & $\mathrm{FDI}_{\mathrm{t}-1}$ & $\mathrm{DCPS}_{\mathrm{t}-1}$ & $\mathrm{M} 2_{\mathrm{t}-1}$ & $\mathrm{INF}_{\mathrm{t}-1}$ & $\mathrm{R}^{2}$ & $\mathrm{DW}$ \\
\hline $\mathrm{GDP}_{\mathrm{t}}$ & 1.651 & - & $0.461^{* *}$ & $-0.185^{* * *}$ & $0.103^{*}$ & 0.129 & 0.79 & 2.04 \\
$\mathrm{FDI}_{\mathrm{t}}$ & -1.098 & $0.554^{* *}$ & - & $0.135^{*}$ & -0.001 & -0.465 & 0.86 & 2.29 \\
\hline
\end{tabular}

***Denotes statistical significance at $1 \%$ level. ** Denotes statistical significance at $5 \%$ level. * Denotes statistical significance at $10 \%$ level.

Table 5, provides the short run coefficients among the parameters. The results indicated that the lag value of GDP and FDI has a positive effect on economic growth in the short-run. However, different from the long-run estimation the variable $\mathrm{M}_{2}$ is no longer significant which indicated that $\mathrm{M}_{2}$ has a positive effect on the economic growth only in the long run. In the short-run, the variable inflation rate has a negative relationship with economic growth. These results consist with the findings of Faria and Carneiro (2001) for Brazil and Feeny, Iamsiraroj, and McGillivray (2014) for Pacific Island. The variable domestic credit private sector was no longer significant. Concerning to FDI model the short-run results confirm that economic growth and domestic credit to private sector both are determinant in the amount of FDI in the country.

The ECMt $_{-1}$ for the two models were negative and statistically significant at one percent level. It shows how fast short term disturbances return to the long-run equilibrium. For GDP model the value of -0.99 indicated that the short-run deviations from long-run were corrected about $99 \%$ each year. While for FDI the $\mathrm{ECM}_{\mathrm{t}-1}$ value of -0.728 indicated that the short-run deviations for the long-run were corrected about 72.8 . These models pass all the diagnostic test such as heteroscedasticity, the normality of the residues, and serial correlation. Besides, Ramsey's reset test also shows that the model is well specified.

Table 5. Short-run results

\begin{tabular}{|c|c|c|c|c|}
\hline Equation model & \multicolumn{2}{|c|}{$\mathrm{GDP}_{\mathrm{t}}$} & \multicolumn{2}{|c|}{$\mathrm{FDI}_{\mathrm{t}}$} \\
\hline $\mathrm{GDP}_{\mathrm{t}}$ & \multicolumn{2}{|c|}{-} & \multicolumn{2}{|c|}{$0.406^{* *}$} \\
\hline $\mathrm{GDP}_{\mathrm{t}-1}$ & \multicolumn{2}{|c|}{$0.467 * *$} & \multicolumn{2}{|c|}{-} \\
\hline $\mathrm{FDI}_{\mathrm{t}}$ & \multicolumn{2}{|c|}{$0.456^{*}$} & \multicolumn{2}{|c|}{-} \\
\hline $\mathrm{INF}_{\mathrm{t}}$ & \multicolumn{2}{|c|}{0.045} & \multicolumn{2}{|c|}{-0.079} \\
\hline $\mathrm{INF}_{\mathrm{t}-1}$ & \multicolumn{2}{|c|}{$-0.355^{*}$} & \multicolumn{2}{|c|}{0.229} \\
\hline $\mathrm{M} 2_{\mathrm{t}}$ & \multicolumn{2}{|c|}{-0.136} & \multicolumn{2}{|c|}{-0.0002} \\
\hline $\mathrm{DCPS}_{\mathrm{t}}$ & \multicolumn{2}{|c|}{-0.151} & \multicolumn{2}{|c|}{$0.369 * * *$} \\
\hline $\operatorname{DCPS}_{\mathrm{t}-1}$ & \multicolumn{2}{|c|}{-0.198} & \multicolumn{2}{|c|}{$0.199 *$} \\
\hline $\mathrm{ECM}_{\mathrm{t}-1}$ & \multicolumn{2}{|c|}{$-0.988 * * *$} & \multicolumn{2}{|c|}{$-0.728 * * *$} \\
\hline Diagnostic test & \multicolumn{2}{|c|}{ T-Statistic (probability) } & \multicolumn{2}{|c|}{ T-Statistic (probability) } \\
\hline J-B Normal & 0.5707 & $(0.752)$ & 1.897 & $(0.387)$ \\
\hline Breusch-Godfrey serial correlation & 0.221 & $(0.895)$ & 2.851 & $(0.240)$ \\
\hline White Heteroscedasticity & 7.121 & $(0.789)$ & 3.492 & $(0.941)$ \\
\hline Ramsey Reset & 1.142 & $(0.274)$ & 0.921 & $(0.371)$ \\
\hline
\end{tabular}

*** Denotes statistical significance at $1 \%$ level. ** Denotes statistical significance at 5\% level. * Denotes statistical significance at $10 \%$ level. 


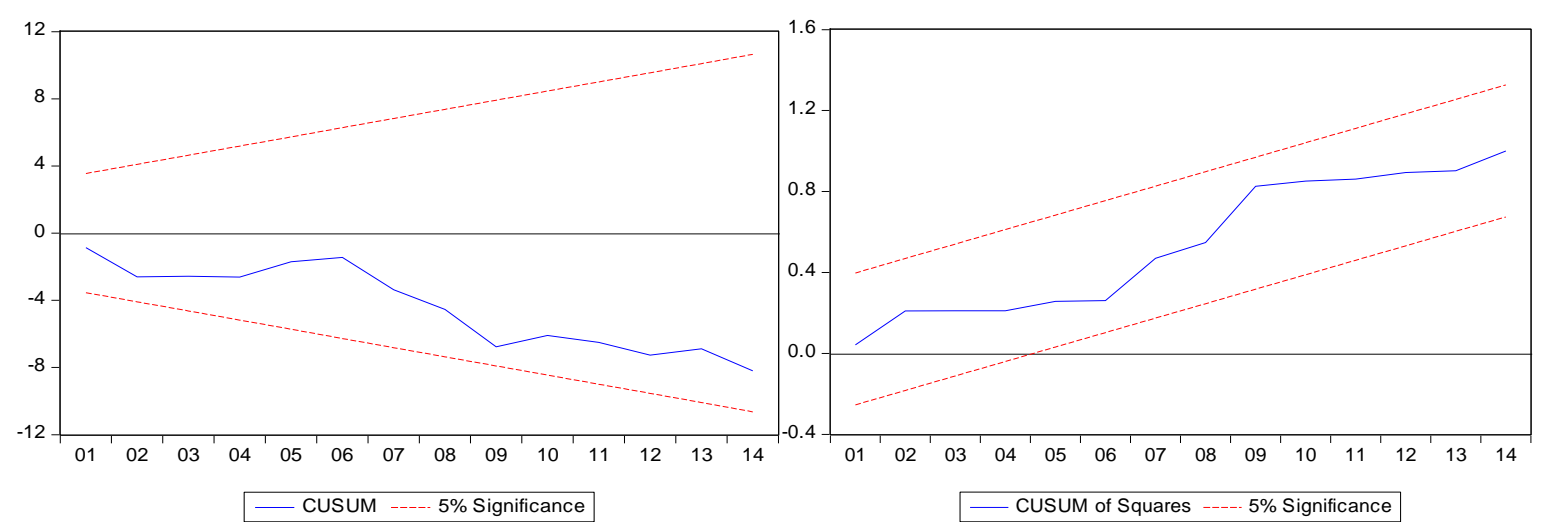

Figure 2. Plot of CUSUM and CUSUM of squares test for $\mathrm{GDP}_{\mathrm{t}}$ model
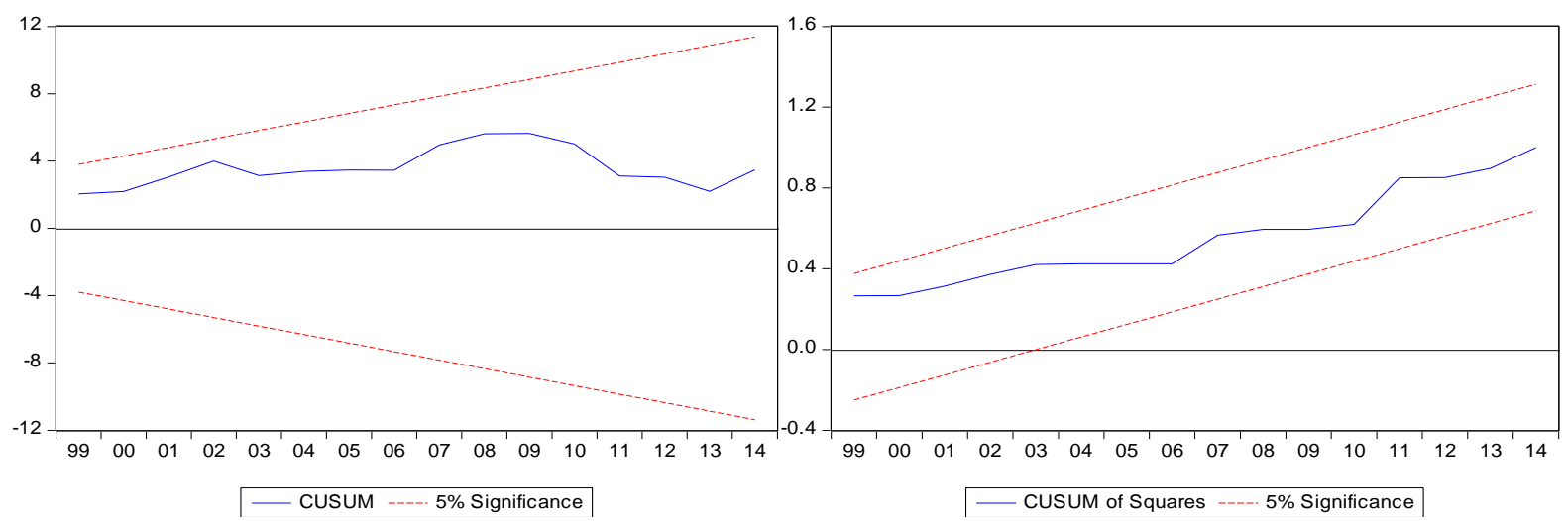

Figure 3. Plot of CUSUM and CUSUM of squares test for FDI $\mathrm{t}_{\mathrm{t}}$ model

The Figure 2 and Figure 3 provide the plot of cumulative sum of recursive residual (CUSUM) and the plot cumulative sum of squares of recursive residual (CUSUM sq) for the series model GDP ${ }_{t}$ and FDI . The CUSUM . and CUSUM sq illustrate the stability of the parameters in the model (Pesaran et al., 2001). The results obtained from the Figure 2 and 3 confirms the stability of the parameters, given that all the coefficients values lie inside the critical bound values.

\subsection{Granger Causality Results}

After applying the cointegration analysis and seeing that the variables are cointegrated give raise to determine ECM-granger causality to see the direction of the causality between the variables. As mentioned in the previous section, if cointegration exists, it has to be either bidirectional unidirectional or neutral causality between the variables. The results are obtained by using the error correction model pairwise with granger causality and Wald test. The Wald F-statistics of the lagged variables indicated the short run causality effects.

The results of granger causality analysis are presented in table 6 and it reveals interesting finding. The results indicated that there is a bidirectional granger causality between FDI and economic growth per capita at $10 \%$ significance level. This result differs from the result found by Alves (2011) that stated that GDP does granger cause FDI but FDI does not granger cause GDP for the economy of Cabo Verde. On the other hand, the F-statistic demonstrated that at $10 \%$ level there is a unidirectional granger causality between inflation and GDP at $5 \%$ level.

Table 6. Granger causality results

\begin{tabular}{|c|c|c|c|c|c|c|}
\hline Dependent variable & & & atistics & & & Direction of causality \\
\hline & $\Delta \mathrm{GDP}$ & $\Delta \mathrm{FDI}$ & $\Delta \mathrm{M}_{2}$ & $\triangle \mathrm{DCPS}$ & $\Delta I N F$ & \\
\hline$\Delta \mathrm{GDP}$ & - & $4.08^{*}$ & 0.97 & 1.17 & $3.15^{*}$ & $\mathrm{FDI} \rightarrow \mathrm{GDP}, \mathrm{INF} \rightarrow \mathrm{GDP}$ \\
\hline$\Delta \mathrm{FDI}$ & $3.77^{*}$ & - & 0.72 & $4.95^{* *}$ & 0.77 & $\mathrm{DCPS} \rightarrow \mathrm{FDI}, \mathrm{GDP} \rightarrow \mathrm{FDI}$ \\
\hline$\Delta \mathrm{M} 2$ & 0.001 & 2.11 & - & $4.74 * *$ & $4.98 * * *$ & $\mathrm{DCPS} \rightarrow \mathrm{M}_{2}, \mathrm{INF} \rightarrow \mathrm{M}_{2}$ \\
\hline$\triangle \mathrm{DCPS}$ & 0.42 & 0.40 & 1.82 & - & 0.22 & \\
\hline$\Delta \mathrm{INF}$ & 0.51 & 0.05 & 1.77 & 0.52 & - & \\
\hline
\end{tabular}


The results also indicated that domestic credit to private sector granger causes FDI. These results go in line with results found by Nezakati, Fakhreddin, and Vaighan (2011) for Malaysia. The F-statistic of the explanatory variables also suggested that there is a unidirectional causal relationship from DCPS to $\mathrm{M}_{2}$ as well as the unidirectional causal relationship between inflation to $\mathrm{M}_{2}$ at $5 \%$ and $1 \%$ level respectively.

\section{Conclusion}

This paper examines the long-run and the short-run relationship among the series of variables such as economic growth, foreign direct investment, domestic credit to private sector, money supply and inflation rate for the period of 1987 to 2014. To do the analysis we first applied the ADF and PP test to determine the stationarity of the variables. The bound test approach to cointegration was employed to determine the existence of long-run relationship among the variables in the study. The results indicated the existence of cointegration when GDP and FDI are the dependent variables. The results also indicated that FDI, money supply have a positive effect on the economic growth of the country. What is interesting is that foreign direct investment increase economic growth not only in the short-run but also in the long-run. Moreover, the results indicated that economic growth and domestic credit to private sector are an important determinant of the amount of FDI inflow into the country. Turning to granger causality our results suggested that there is a bidirectional granger causality between GDP and FDI which indicated that FDI granger causes GDP and vice versa. Besides, others important results illustrated that domestic credit private sector granger causes FDI.

Similar to various belief, we conclude that FDI stimulates economic growth in Cabo Verde. Furthermore, we find that economic growth and DCPS are important determinants of FDI in the country. Even though, the research presents some limitations, such as the small sample size this finding could be very important for the assimilations of appropriate policy to attract more foreign direct investment to the country. The Cabo Verde government should support the improvement of some sectors in order to achieve higher benefit from the amount of FDI inflow in Cabo Verde. The government should ensure to achieve a sound financial development, reduce the public spending and stimulate the private sector to take on a larger participation in investment and economic growth.

\section{References}

AfDB. (2012). Cape Verde: A Success Story. Retrieved from ADB, ADF: https://www.afdb.org/fileadmin/uploads/afdb/Documents/Project-and-Operations/Cape\%20Verde\%20-\%20 A\%20Success\%20Story.pdf

AfDB. (2014). Cabo Verde Country Strategy paper 2014-2018. Africa Development Bank. Retrieved from https://www.afdb.org/fileadmin/uploads/afdb/Documents/Project-and-Operations/2014-2018_-_Cape_Verd e_Country_Strategy_Paper.pdf

Alfaro, L., Chanda, A., Kalemli-Ozcan, S., \& Sayek, S. (2004). FDI and economic growth: The role of local financial markets. Journal of International Economics, 64(1), 89-112. http://doi.org/10.1016/S0022-1996(03)00081-3

Alkhuzaim, W. (2014). Degree of financial development and economic growth in Qatar: Cointegration and causality analysis. International Journal of Economics and Finance, 6(6), 57. http://dx.doi.org/10.5539/ijef.v6n6p57

Almfraji, M. A., Almsafir, M. K., \& Yao, L. (2014). Economic growth and foreign direct investment inflows: The case of Qatar. Procedia-Social and Behavioral Sciences, 109, 1040-1045. https://doi.org/10.1016/j.sbspro.2013.12.586

Alves, I. V. (2011). O impacto do investimento directo estrangeiro no crescimento económico de Cabo Verde [The impact of foreign direct investment on Cabo Verde's economic growth]. (Master Degree), ISCTE, Lisboa. Retrieved from http://hdl.handle.net/10071/4164

Ariç, K. H. (2014). The effects of financial development on economic growth in the European Union: A panel data analysis. International Journal of Economic Practices and Theories, 4(4), 466-471.

Azman-Saini, W., Law, S. H., \& Ahmad, A. H. (2010). FDI and economic growth: New evidence on the role of financial markets. Economics Letters, 107(2), 211-213. http://doi.org/10.1016/j.econlet.2010.01.027

Balasubramanyam, V. N., Salisu, M., \& Sapsford, D. (1996). Foreign direct investment and growth in EP and IS countries. The Economic Journal, 92-105. https://doi.org/10.2307/2234933

Barro, R. J., \& Sala-i-Martin, X. (1995). Economic Growth. Cambridge, MA: McGraw-Kill. 
BCV. (2015). Relatório Anual de $2015 \quad[2015$ annual report]. Retrieved from http://www.bcv.cv/vPT/Publicacoes\%20e\%20Intervencoes/Relatorios/Relatorio\%20Anual/Paginas/Relatori oAnual.aspx

Bekhet, H. A., \& Al-Smadi, R. W. (2015). Determinants of Jordanian foreign direct investment inflows: Bounds testing approach. Economic Modelling, 46, 27-35. http://doi.org/10.1016/j.econmod.2014.12.027

Belloumi, M. (2014). The relationship between trade, FDI and economic growth in Tunisia: An application of the autoregressive distributed lag model. Economic Systems, 38(2), 269-287. http://doi.org/10.1016/j.ecosys.2013.09.002

Bengoa, M., \& Sanchez-Robles, B. (2003). Foreign direct investment, economic freedom and growth: new evidence from Latin America. European Journal of Political Economy, 19(3), 529-545. http://doi.org/10.1016/S0176-2680(03)00011-9

Bertocco, G. (2008). Finance and development: Is Schumpeter's analysis still relevant? Journal of Banking \& Finance, 32(6), 1161-1175. https://doi.org/10.1016/j.jbankfin.2007.10.010

Blin, M., \& Ouattara, B. (2009). Foreign direct investment and economic growth in Mauritius: Evidence from bounds test cointegration. ÉConomie Internationale, (1), 47-61.

Blomstrom, M., Lipsey, R. E., \& Zejan, M. (1992). What explains developing country growth? Retrieved from http://www.nber.org/papers/w4132

Borensztein, E., De Gregorio, J., \& Lee, J. W. (1998). How does foreign direct investment affect economic growth? Journal of International Economics, 45(1), 115-135.

Brito, J. A. (2014). Diagnóstico do Crescimento da Economia Cabo-verdiana [Growth Diagnostic of Cape Verdean Economy]. Retrieved from University Library of Munich, Germany.

Cetin, H. (2016). The Relationship between Turkey's Financial Indicators and Economic Growth Rates. Journal of Economics Business and Management, 4(1), 36- 39. https://doi.org/10.7763/JOEBM.2016.V4.363

De Jager, J. (2004). Exogenous and Endogenous Growth. University of Pretoria ETD.

Dickey, D. A., \& Fuller, W. A. (1979). Distribution of the estimators for autoregressive time series with a unit root. J. Am. Stat. Assoc., 74(366), 427-431. http://dx.doi.org/10.1080/01621459.1979.10482531

Dritsaki, C., \& Stiakakis, E. (2014). Foreign direct investments, exports, and economic growth in Croatia: A time series analysis. Procedia Economics and Finance, 14, 181-190. https://doi.org/10.1016/S2212-5671(14)00701-1

Faisal, F., Muhamad, P. M., \& Tursoy, T. (2016). Impact of Economic Growth, Foreign Direct Investment and Financial Development on Stock Prices in China: Empirical Evidence from Time Series Analysis. International Journal of Economics and Financial, 6(4), 1998-2006.

Faria, J. R., \& Carneiro, F. G. (2001). Does high inflation affect growth in the long and short run? Journal of Applied Economics, 4(1), 89-105.

Feeny, S., Iamsiraroj, S., \& McGillivray, M. (2014). Growth and foreign direct investment in the Pacific Island countries. Economic Modelling, 37, 332-339. http://doi.org/10.1016/j.econmod.2013.11.018

Hermes, N., \& Lensink, R. (2003). Foreign direct investment, financial development and economic growth. The Journal of Development Studies, 40(1), 142-163. http://dx.doi.org/10.1080/00220380412331293707

Narayan, P. K., \& Smyth, R. (2008). Energy consumption and real GDP in G7 countries: New evidence from panel cointegration with structural breaks. Energy Economics, 30(5), 2331-2341. https://doi.org/10.1016/j.eneco.2007.10.006

Nezakati, H., Fakhreddin, F., \& Vaighan, B. M. (2011). Do local banks credits to private sector and domestic direct investments affect FDI inflow?(Malaysia evidence). World Applied Sciences Journal, 15(11), 1576-1583.

Nshimyumuremyi, A., \& Simpasa, A. (2016). Cabo Verde, african economic outlook cabo verde 2016. AfDB, OECD, UNDP. Retrieved from http://www.africaneconomicoutlook.com

Odhiambo, N. M. (2009). Energy consumption and economic growth nexus in Tanzania: An ARDL bounds testing approach. Energy Policy, 37(2), 617-622. https://doi.org/10.1016/j.enpol.2008.09.077

OECD. (2002). Foreign Direct Investment for Development: Maximizing Benefits, Minimizing Costs. OECD, 
Paris. Retrieved from https://www.oecd.org/investment/investmentfordevelopment/1959815.pdf

Pesaran, M. H., \& Shin, Y. (1998). An autoregressive distributed-lag modelling approach to cointegration analysis (S. E. Strom Ed.). Cambridge, MA: Cambridge University Press.

Pesaran, M. H., \& Shin, Y. (1999). An autoregressive distributed lag modeling approach to cointegration analysis I (S. E. Strom Ed.). Cambridge: Cambridge University Press.

Pesaran, M. H., Shin, Y., \& Smith, R. J. (2001). Bounds testing approaches to the analysis of level relationships. Journal of Applied Econometrics, 16(3), 289-326. https://doi.org/10.1002/jae.616

Phillips, P. C., \& Perron, P. (1988). Testing for a unit root in time series regression. Biometrika, 335-346. https://doi.org/10.2307/2336182

Razmi, M. J., \& Refaei, R. (2013). The effect of trade openness and economic freedom on economic growth: The case of Middle East and East Asian countries. International Journal of Economics and Financial Issues, 3(2), 376.

Romer, P. M. (1990). Endogenous technological change. Journal of political economy, 98(5, Part 2), S71-S102. https://doi.org/10.1086/261725

Semedo, A. C. (2007). Avaliação da Sustentabilidade do Défice da Balança Corrente Cabo-Verdiana [Sustainability Assessment of the Cabo-Verdiana Current Balance Deficit]. Banco de Cabo Verde, Praia. Retrieved

http://www.bcv.cv/SiteCollectionDocuments/Publicacoes\%20e\%20Intervencoes/Working\%20Papers/2007/ caderno05.pdf

WorldBank. (2016). Macro poverty outlook, Cabo Verde recent developments. The World Bank. Retrieved from http://pubdocs.worldbank.org/en/897091477329246138/mpo-am16-cpv.pdf

\section{Notes}

Note 1 . In 2008, the primary sector accounted for $11.1 \%$ of GDP, the secondary sector represented $13.6 \%$ while the tertiary sector accounted for $75.3 \%$ of GDP. (INE).

Note 2. The FDI inflow in the country has concentrated, with a great preponderance, in the tourism and services sector. The industry sector accounting for about $2 \%$ of total FDI into the country (aicep, 2016).

Note 3. Sourced: UNCTAD data center.

Note 4. Sourced: Cabo Verde National Institute of Statistics (INE) database.

Note 5. Endogenous growth theory assumes that by introduction technological progress in the production process can promote long-term economic growth in the host country (De Mello, 1999; Herzer et al., 2008).

\section{Copyrights}

Copyright for this article is retained by the author(s), with first publication rights granted to the journal.

This is an open-access article distributed under the terms and conditions of the Creative Commons Attribution license (http://creativecommons.org/licenses/by/4.0/). 